\title{
Serum Copper Levels in Different Stages of Cervical Cancer in Manipur
}

\author{
Davina Hijam¹, Abhishek Dubey², Victoria Laishram², L. Jaichand ${ }^{3}$, Th Ibetombi Devi ${ }^{4}$ \\ 1Assistant Professor, 2PGT, 4Professor, Department of Biochemistry, \\ 3Professor, Department of Radiotherapy, \\ Regional Institute of Medical Sciences, Imphal, Manipur, India.
}

\begin{abstract}
Introduction: Cervical cancer is one of the most common cancer leading to death of women worldwide. It is very important to diagnose the disease as early as possible to save a number of lives. This study was conducted to evaluate the status of serum copper level among the patients with cervical cancer.
\end{abstract}

Aims and Objects: To evaluate serum copper levels of cervical cancer patients before and after the treatment and also to compare serum copper level among the cervical cancer patients along with age matched normal, healthy controls.

Materials and Methods: Fifty (50) clinically and histopathologically confirmed cases of cervical cancer patients who attended or admitted in Obstetrics and Gynaecology Department or Radiotherapy Department, RIMS were selected for the study. Cases were grouped as subgroups i.e. stage I, II, III and IV. Thirty age matched healthy normal females were taken as control. Serum copper level was estimated by colorimetric method of Di-Br-PAESA.

Results: The mean \pm SD age of patients was $57.78 \pm 16.78$ years whereas as that of control was $57.74 \pm 12.12$ years. Out of 50 cervical cancer patients, $30(60 \%)$ cases were nonoperable. There was a significant increase of serum copper level among the cases $(221.19 \pm 66.20 \mu \mathrm{g} / \mathrm{dl})$ when compared with controls $(121.85 \pm 5.54 \mu \mathrm{g} / \mathrm{dl})$. Maximum number of cases (26) were in the range of $201-250 \mu \mathrm{g} / \mathrm{dl}$ serum copper level. Serum copper level decreased significantly $(p<.001)(170.32$ $\pm 17.66 \mu \mathrm{g} / \mathrm{dl})$ after treatment when compared with before treatment levels $(221.19 \pm 66.20 \mu \mathrm{g} / \mathrm{dl})$. Serum copper level of

\section{INTRODUCTION}

Cervical cancer is a global public health problem. It is one of the most common cancer leading to the deaths of women worldwide. ${ }^{1}$ An estimated new cases of 5,30, 000 and 2, 75, 000 deaths occurred annually out of which $88 \%$ occur in developing countries. ${ }^{2}$ In India, cervical cancer ranked as the first most frequent cancer among women between 15 and 44 years of age..$^{3,4}$

Trace elements and free radicals have been implicated in the etiology of cancer. ${ }^{5}$ Copper as a cofactor of various redox enzymes can bind to proteins and nucleic acids and cause oxidation of lipids and proteins. The formation of deleterious free radicals is also enhanced by copper ions. Copper is essential for the cases increased with the progress of the disease. There was a positive correlation between serum copper level and stages of the disease. In all stages copper levels decreased significantly after treatment.

Conclusion: There was increased serum copper level among cervical cancer which correlated significantly with the stages of cancer cervix. This indicate that copper can be used as a parameter for screening cervical cancer and also it can be used as a valuable prognostic indicator for monitoring disease activity.

Key words: Copper, Cervical cancer, Manipur, Stages of cervical cancer.

\section{${ }^{*}$ Correspondence to:}

Dr Davina Hijam

Assistant Professor,

Department of Biochemistry,

Regional Institute of Medical Sciences, Imphal, Manipur, India.

\section{Article History:}

Received: 21-07-2016, Revised: 06-08-2016, Accepted: 10-08-2016

\begin{tabular}{|l|c|}
\hline \multicolumn{2}{|c|}{ Access this article online } \\
\hline $\begin{array}{l}\text { Website: } \\
\text { www.ijmrp.com }\end{array}$ & \\
\hline DOI: & \\
10.21276/ijmrp.2016.2.5.006 & \\
\hline
\end{tabular}

proper functioning of metalloenzymes like cytochrome $\mathrm{C}$ oxidase, a amylase, carbonic anhydrase, superoxide dismutase, tyrosinase, dopamine hydroxylase, ceruloplasmin, ALA synthase, catalase, uricase and ascorbic acid oxidase. Copper, Zinc and Selenium are important cofactor for several enzymes that play a role in maintaining DNA integrity. ${ }^{6}$

The procarcinogenic activity of copper was found to be related to the formation of respective reactive oxygen radicals that impair DNA thread and to initiation of angiogenesis of the tumor. ${ }^{7}$

Several investigators ${ }^{8-10}$ studied serum copper level in malignant diseases like carcinoma, sarcoma, lymphoma and they have reported a persistent increase of serum copper level. Increase 
serum copper level is also reported in all types of genital cancers and statistically significant value in cervical cancers. ${ }^{11,12} \mathrm{~A}$ positive correlation between serum copper level and grades of cervical cancer were noticed showing a linear progression of copper level with increasing stages of the disease. ${ }^{13-14}$ Serum copper level increases with disease progression. ${ }^{15}$

Serum copper level decreases after treatment in cancer cervix irrespective of the age of the disease. ${ }^{16}$ Arumanayagam et al $1993^{17}$ reported a significantly marked increase of serum copper level in advanced stage of carcinoma cervix and indicated that ceruloplasmin could discriminate between large inoperable tumor and early cervical cancers.

The elevation of copper in cervical cancer might be due to mobilisation from tissue to serum. ${ }^{18}$ copper can interact directly with the bases G-C sites. Copper may also elaborate other free radical species such as $\mathrm{OH}$ ' leading to inactivation or loss of certain tumor suppressor gene leading to the initiation and progression of carcinogenesis.

However other investigators ${ }^{19,20}$ reveals in their studies that the differences of copper level between controls and cancer cervix are not enough to serve as marker for the invasive cervical lesion.

Because of contradictory reports in the literature and maximum reports suggesting role of serum copper in the evaluation of disease activity and as a prognostic tool in the management, an attempt is made to study serum copper level among the different stages of cervical cancer in Imphal, Manipur.

\section{MATERIALS AND METHODS}

The study was carried out in the Department of Biochemistry in collaboration with Department of Obstetrics and Gynaecology as well as Radiotherapy Department, Regional Institute of Medical Sciences and Hospital, Imphal, Manipur during the period from September 2013 to August 2015.

The present study included 50 patients with carcinoma cervix, confirmed by clinical and histopathological examination and who were admitted or attended in the Department of Obstetrics and Gynaecology as well as Radiotherapy Department irrespective of age. Another age matched 30 normal healthy females were taken as controls. Cancer cervix patients were divided into four different groups according to their clinical stages (I, II, III, IV).

\section{Exclusion criteria}

1. Patients with chronic liver disease

2. Renal disease

3. Diabetes mellitus

4. Active hemorrhagic attacks

5. Patients receiving estrogen or other hormone therapy After obtaining prior consent, $2 \mathrm{ml}$ of venous blood was collected in a sterile vial from the patients as well as controls. Lipemic and hemolysed blood samples were discarded. Reagents used in this study were of analytic grade. The organic solvents were redistilled before use.

Estimation of serum copper was done based on Di-Br-PAESA method ${ }^{21}$ using copper kit reagent obtained from Crest Biosystems Pvt Ltd, Gitanjali, Goa, India.

All the results were expressed in mean $\pm S D$. Statistical analysis was done by using SPSS version 17 software. Standard t-test was considered as significant $(<0.05)$ whereas $p<0.001$ was considered as highly significant.

Study was approved by the institutional ethical committee, regional Institute of Medical Sciences, Imphal. Written informed consent was obtained from all individuals participating in this study after explaining nature of the study to them and confidentiality was maintained.

\section{RESULTS AND OBSERVATIONS}

Maximum number (16) i.e. $32 \%$ of cervical cancer patients were in age group of $61-70$ years followed by $13(26 \%)$ cases within $51-60$ years of age. The mean age of cervical cancer patients was 57.78 \pm 16.78 years whereas that of control cases being $57.74 \pm 12.12$ years (table 1). Majority of the cases were Hindus.

Out of 50 cases of cancer cervix 20 cases were operable and 30 cases were nonoperable.

There was a significant $(p<0.001)$ increase of copper level $(221.19 \pm 66.20 \mu \mathrm{g} / \mathrm{dl})$ among the cancer cases when compared with controls (table 2)

Maximum cases (26) were in the range of $201-250 \mu \mathrm{g} / \mathrm{dl}$ copper level followed by $12(24 \%)$ cases in the range of $251-300 \mu \mathrm{g} / \mathrm{dl}$ of copper level. (table 3 )

The mean \pm SD copper level of cancer cervix cases showed a significant decrease $(p<0.001)$ after treatment (table 4).

Table 1: Age wise distribution of control and cervical cancer cases

\begin{tabular}{|c|c|c|c|c|}
\hline \multirow{2}{*}{$\begin{array}{l}\text { Age group } \\
\text { (years) }\end{array}$} & \multicolumn{2}{|c|}{ Control $(n=30)$} & \multicolumn{2}{|c|}{ Cases $(n=50)$} \\
\hline & Number & Percent & Number & Percent \\
\hline$<40$ & 4 & 13.33 & 8 & 16 \\
\hline $41-50$ & 3 & 10.00 & 7 & 14 \\
\hline $51-60$ & 5 & 16.67 & 13 & 26 \\
\hline $61-70$ & 8 & 26.67 & 16 & 32 \\
\hline$>71$ & 10 & 33.33 & 6 & 12 \\
\hline Total & 30 & 100.00 & 50 & 100 \\
\hline Mean \pm SD & \multicolumn{2}{|c|}{$57.74 \pm 12.12$} & \multicolumn{2}{|c|}{$57.78 \pm 16.78$} \\
\hline
\end{tabular}

Table 2: Mean serum copper \pm SD in controls and study cases

\begin{tabular}{lccc}
\hline & Controls & Malignant cases & P value \\
\hline $\begin{array}{l}\text { S. Copper level }(\boldsymbol{\mu g} / \mathrm{dl}) \\
\text { Mean } \pm \text { SD }\end{array}$ & $121.85 \pm 5.54$ & $221.19 \pm 66.20$ & $<0.001$ \\
\hline
\end{tabular}


Davina Hijam et al. Serum Copper Level in Cervical Cancer

Table 3: Distribution of malignant cases by copper level

\begin{tabular}{lcc}
\hline Serum copper level $(\boldsymbol{\mu g} / \mathrm{dl})$ & Study cases & Percentage \\
\hline $\mathbf{1 5 0 - 2 0 0}$ & 6 & 12 \\
$\mathbf{2 0 1}-\mathbf{2 5 0}$ & 26 & 52 \\
$\mathbf{2 5 1}-\mathbf{3 0 0}$ & 12 & 24 \\
$\mathbf{3 0 1}-\mathbf{3 5 0}$ & 5 & 10 \\
$>\mathbf{3 5 1}$ & 1 & 2 \\
\hline
\end{tabular}

Table 4: Serum copper levels before and after treatment

\begin{tabular}{lccc}
\hline Parameter & Before treatment & After treatment & P value \\
\hline $\begin{array}{l}\text { S. Copper level }(\boldsymbol{\mu g} / \mathrm{dl}) \\
\text { Mean } \pm \text { SD }\end{array}$ & $221.19 \pm 66.20$ & $170.32 \pm 17.66$ & $<0.001$ \\
\hline
\end{tabular}

Table 5: Serum copper level (mean \pm SD) among different stages of cervical cancers

\begin{tabular}{lccc}
\hline Stages of cervical & No of cases & \multicolumn{2}{c}{ S. Copper level (Mean \pm SD) $(\boldsymbol{\mu g} / \mathrm{dl})$} \\
\cline { 2 - 4 } cancer & & Before treatment & After treatment \\
Stage I & 8 & $202.5 \pm 10.6$ & $160.03^{* \star *}$ \\
Stage II & 13 & $215.5 \pm 9.63$ & $165.85 \pm 10.6^{* * *}$ \\
Stage III & 14 & $229.33 \pm 16.65$ & $175.33 \pm 3.05^{* * *}$ \\
Stage IV & 15 & $237.5 \pm 15.85$ & $180.62 \pm 11.55^{* \star *}$ \\
\hline
\end{tabular}

The mean \pm SD copper level of cancer cervix cases showed a significant decrease $(p<0.001)$ after treatment (table 4$)$. Serum copper level (mean $\pm \mathrm{SD}$ ) of all stages of the study group indicated a significant decrease after treatment (table 5).

Maximum number (15) of carcinoma cervix cases were in the stage IV whereas 14 cases were in stage III and 13,8 cases were in stage II and I respectively. Comparison of stage I with other advanced stages there exhibited positive correlation.

\section{DISCUSSION}

In the present study an attempt was made to find out the changes in serum copper level among cervical cancer patients. Blood samples were collected from all the cases and controls for the estimation of serum copper levels before and after treatment (surgery, chemotherapy, radiotherapy or combined), blood samples of all study cases were estimated for serum copper level. The present study shows that maximum number of cases were in age group of $61-70$ years of age and mean age \pm SD of the cases was $57.78 \pm 16.78$ years (table 1 ).

Dan LL (2001) ${ }^{22}$ reported that two third of all cancer cases were over 65 years of age. As age advances incidence of cancer both in male and female increases. Maximum number of Hindu cases in this study might be due to the reason that the study was carried out in Hindu dominated area. Most of the cases (60\%) were nonoperable. As there is no population based screening programme in India, $70-80 \%$ of cervical cancer patients are diagnosed at advanced stages (stage III and IV) with very poor long term survival. ${ }^{23}$

As shown in table 2 , there was a significant $(p<0.001)$ increase in the level of serum copper among carcinoma cervix cases when compared with the control. Similar results were reported by previous investigators. ${ }^{11-14}$ It was hypothesized that ceruloplasmin were resialylated at the tumor cell surface and this leads to a decrease in its catabolism, a process that could account for increase in serum copper level in patients with cancer. ${ }^{24}$ Copper also play some role in angiogenesis which is required for development of new tissue as well as tumor growth through mediation of copper dependent amine oxidases activity. ${ }^{7}$

As a result of presence of free copper ions, promotion of free radical generation leading to oxidative damage of many biological targets from single macromolecule such as lipoprotein, DNA, thiol containing enzyme and intact cells including hepatocytes.

Fisher GL et al (1981) ${ }^{25}$ reported that the increase copper level among the cases might result from increase liver production of ceruloplasmin as an inflammatory response to the cancer or from a tumor induced catabolism of serum ceruloplasmin. Whereas Cohen D et al (1979)26 suggested that increase copper level might be due to increased absorption from gut.

The elevation of copper might be a physiological response designed to active superoxide dismutase on other copper enzymes in cancer cell to inhibit their growth. ${ }^{27}$

The maximum number of cervical cancer patients (26) were in serum copper level of $201-250 \mu \mathrm{g} / \mathrm{dl}$ (tab III). Serum copper level decreased significantly after treatment (table 4). There was a significant increase of copper level in advanced stages. Copper level showed a positive correlation with the stages of cancer. In all the stages, copper level decreased after treatment.

This study correlates with the findings of Margolith EJ 198723, who found copper level correlated with stages of cervical cancers except in ovarian neoplasm. Trupti DR (2015) ${ }^{11}$ reported higher level of serum copper level in different stages of cervical cancer when compared with control.

Chen et al $1990^{16}$ evaluated copper level after treatment and reported to reduce level as treatment is ongoing. Saxena $\mathrm{P}$ et al $(2002)^{13}$ found a decrease in serum copper level $(p<0.001)$ after treatment of cancer cervix cases. 


\section{CONCLUSION}

The results of this study are correlated with the results of previous studies. It indicates a possible clinical usefulness of estimating serum copper levels among the patients with cervical cancer and suggest a role in the evaluation of disease activity and as a prognostic tool in the management of disease and as a check parameter of recurrence.

\section{ACKNOWLEDGEMENT}

We are thankful to the patients who have given their consent to carry out this study.

\section{REFERENCES}

1. Ferlay J, Shin HR, Bray F, Forman D, Mathers C, Parkin DM. Estimates of worldwide burden of cancer in 2008: GLOBOCAN 2008. Int J Cancer 2010;127(12):2893-917.

2. Kaarthigeyan K. Cervical cancer in India and HPV vaccination. Indian Journal of Medical and Paediatric Oncology: Official Journal of Indian Society of Medical \& Paediatric Oncology 2012;33(1):7-12.

3. Farhath S, Vijaya PP, Mumtaj P. Cervical cancer: is vaccination necessary in India? Asian Pac J Cancer Prev 2013;14(4):2681-4.

4. Thulaseedharan JV, Malila N, Hakama M, et al. Socio demographic and reproductive risk factors for cervical cancer - a large prospective cohort study from rural India. Asian Pac J Cancer Prev 2012;13(6):2991-5.

5. Nayak SB, Bhat VR, Upadhyay D, Udupa SL. Copper and ceruloplasmin status in serum of prostate and colon cancer patients. Indian J Physiol Pharmacol 2003 Jan;47(1):108-10.

6. Mahabir S, Spitz MR, Barrera SL, Beaver SH, Etzel C, Forman MR. Dietary zinc, copper and selenium, and risk of lung cancer. Int J Cancer. 2007 Mar 1;120(5):1108-15.

7. Bobrowska B, Skrajnowska D, Tokarz A. Effect of Cu supplementation on genomic instability in chemically-induced mammary carcinogenesis in the rat. J Biomed Sci 2011;18:95

8. Oyama T, Matsuno K, Kawamoto T, Mitsudomi T, Shirakusa T, Kodama Y. Efficiency of serum copper/zinc ratio for differential diagnosis of patients with and without lung cancer. Biol Trace Elem Res 1994;42(2):115-27.

9. Sanada S, Ogura K, Kiriyama T, Yoshida O. Serum copper and zinc levels in patients with malignant neoplasm of the urogenital tract. Hinyokika Kiyo. 1985;31(8):1299-316.

10. Sharma K, Mittal DK, Kesarwani RC, Kamboj VP, Chowdhery. Diagnostic and prognostic significance of serum and tissue trace elements in breast malignancy.Indian J Med Sci 1994; 48 (10): 227-32.

11. Trupti DR, Rajesh KJ, Arun T, Prakash K. Study of alterations of serum copper and zinc in patients of cervical cancer. Indian Journal of Basic and Applied Medical Research 2015;4(4):91-99.

12. Okonkwo CA, Amegor FO, Gbolade JO . Relationship between Trace Elements and Major Gynaecological Malignancies. Asian journal of medical sciences 2013;5(6):124-127.

13. Saxena P, Yadav S, Salhan S, Bhowmick KT. Serum copper levels in carcinoma of ovary and cervix. Indian $\mathrm{J}$ Physiol Pharmacol 2002;46(2):159-66.

14. Cetinkaya N, Cetinkaya D, Yuce M. Serum copper, zinc levels, and copper. Zinc ratio in healthy women and women with gynecological tumors. Biol Trace Elem Res 1988;18:29-38.
15. Kim SY, Kim JW, Ko YS, Koo JE, Chung HY, Lee-Kim YC. Changes in lipid peroxidation and antioxidant trace elements in serum of women with cervical intraepithelial neoplasia and invasive cancer. Nutr cancer2003; 47(2):126-30.

16. Chen CA, Hwang JL, Kuo TL, Hsieh CY, Huang SC. Serum copper and zinc levels in patients with cervical cancer. J Formos Med Assoc 1990; 89(8):677-82.

17. Arumanayagam M, Wong FW, Rogers M, Swaminathan R. Serum ceruloplasmin, plasma copper concentration and copper to ceruloplasmin ratio in cervical carcinoma. Gynecol Obstet Invest 1993;35(3):175-8.

18. Singh M, Dwivedi S, Singh G, Bajpai M. Serum copper levels in different stages of carcinoma cervix uteri. Indian J Matern Child Health 1990; 1(1):12-4.

19. Altintas A, Vardar MA, Gönlüsen F, Atay Y, Evrüke C, Arpaci A, Aridogan N. Copper, zinc, and magnesium tissue and serum levels in patients with cervical carcinoma. Eur J Gynaecol Oncol 1995;16(4):278-81.

20. Wong WSF, Arumanayagam M, Chang MZA, Copper and zinc levels in patients with cervical neoplasia: Clinical evaluation of the copper/zinc ratio. J. Obstet. Gynaecol 1987;8(1): 53-56.

21. Abe A, Yamashita S, Noma A. Sensitive, direct colorimetric assay for copper in serum. Clin Chem 1989;35(4):552-4.

22. Dan LL. oncology and hematology. In: Fauci AS editors. Harrison's principle of internal medicine. 15th ed. United State of America: McGraw-Hill; 2001.p. 491-502.

23. Margalioth EJ, Udassin R, Cohen C, Maor J, Anteby SO, Schenker JG. Serum copper level in gynecologic malignancies. Am J Obstet Gynecol 1987;157(1):93-6.

24. Fisher GL, Shifrine M. Hypothesis for the mechanism of elevated serum copper in cancer patients. Oncology 1978;35(1):22-5.

25. Fisher GL, Spitler LE, McNeill KL, Rosenblatt LS. Serum copper and zinc levels in melanoma patients. Cancer 1981; 47(7):1838-44.

26. Cohen Y, Epelbaum R, Haim N, McShan D, Zinder O. The value of serum copper levels in non-Hodgkin's lymphoma. Cancer 1984;53(2):296-300.

27. Basu P, Biswas J, Mandal R, Choudhury P. Is interferon-alpha and retinoic acid combination along with radiation superior to chemo-radiation in the treatment of advanced carcinoma of cervix? Indian J Cancer 2006;43(2):54-9.

\section{Source of Support: Nil. Conflict of Interest: None Declared.}

Copyright: (c) the author(s) and publisher. IJMRP is an official publication of Ibn Sina Academy of Medieval Medicine \& Sciences, registered in 2001 under Indian Trusts Act, 1882.

This is an open access article distributed under the terms of the Creative Commons Attribution Non-commercial License, which permits unrestricted non-commercial use, distribution, and reproduction in any medium, provided the original work is properly cited.

Cite this article as: Davina Hijam, Abhishek Dubey, Victoria Laishram, L. Jaichand, Th Ibetombi Devi. Serum Copper Levels in Different Stages of Cervical Cancer in Manipur. Int J Med Res Prof. 2016; 2(5):28-31. 